\title{
Agriculture sphere in the era of Industry 4.0: the world experience and Russian practice of the digital business model building in the agroindustry
}

\author{
Igor Aleksandrov ${ }^{1, *}$, Vitali Daroshka ${ }^{2}$, Alexander Isakov ${ }^{3}$, Irina Chekhovskikh $^{4}$, Ekaterina \\ $\mathrm{Ol}^{4}$, and Elena Borisova ${ }^{5}$ \\ ${ }^{1}$ Petrozavodsk State University, Lenina 33, 185910, Petrozavodsk, Russia \\ ${ }^{2}$ Belarusian Trade and Economic University of Consumer Cooperatives, Oktyabrya Avenue 50. \\ 246012, Gomel, Belarus \\ ${ }^{3}$ The Bonch-Bruevich St. Petersburg State University of Telecommunications (SPbSUT), \\ Bolshevikov Avenue 22, 193232, St. Petersburg, Russia \\ ${ }^{4}$ St. Petersburg State University of Veterinary Medicine, Chernigovskaya 5, 196084, St. Petersburg, \\ Russia \\ ${ }^{5}$ St. Petersburg Branch of The Russian Customs Academy (named after V.B. Bobkov), Sofiyskaya, \\ 52A, 192241, St. Petersburg, Russia
}

\begin{abstract}
The articel is devoted to the study of digital reforms in the agro-industrial complex of Russia and the assessment of opportunities and threats for the sustainable socio-economic development of the country. The article also considers business cases of successful digitalization of agriculture and assesses the economic effects of digital technologies, and forms a scenario for the further development of the agro-industrial complex taking into account global trends in the development of the digital economy.
\end{abstract}

\section{Introduction}

Interest in the formation and scaling up of the practice of introducing digital technologies into the business model of agricultural enterprises is not only a direct consequence of the formation of the new digital economy, but also a number of specific reasons that are explained by the following provisions:

1) agricultural enterprises have a complex non-linear architecture of business relations with both agriculture and the industrial sector;

2) the pressure of world socio-demographic processes, such as the growth of incomes of the population and population, the deterioration of the quality and state of natural resources and climatic indicators, increasingly motivates the search for new solutions to organize food production;

3) increasing public interest in the eco-food and FoodNet segment (food, taking into account personal preferences and recommendations.

\footnotetext{
*Corresponding author: a7830298@gmail.com
} 
For agricultural enterprises of the Russian Federation, in addition to these factors, the low competitive position of agribusiness in world ratings should be noted:

1) according to ITC in the end of 2019 year, Russia was in $19^{\text {th }}$ place in agricultural exports, which is $1,6 \%$ of world exports (Russia climbed to 19th place among the largest agricultural exporters in 2019 (23.04.2020) [Electronic resource] - URL: https://aemcx.ru/2020/04/23/россия-поднялась-на-19-е-место-среди/ (date of access 15.01.2021));

2) according to the Government program "Digital Economy of the Russian Federation," Russia in the end of 2020 year took $37^{\text {th }}$ place in terms of readiness for the digital economy (Digitalization of Russian agricultural production for the period 2018-2025 (December 2018) [Electronic resource] - URL: https://agrardialog.ru/files/prints/apd_studie_2018_russisch_fertig_formatiert.pdf (p. 8; circulation date 14.01.2021 year));

3) the share of the Russian patent applications in the field of innovative agricultural development in the global indicator for 2019 is $~ 1 \%$, and the cost of R\&D projects and startup initiatives in the agro-industrial complex is 50 times lower than in the Netherlands and 10 times compared to Turkey and Poland (Innovative development of the agroindustrial complex in Russia. Agriculture 4.0 [Text]: Doc. to XXI Apr. international scientific. conf. on the problems of economic and social development, Moscow, 2020//Natz. researched. un-t "Higher School of Economics." - M.: Ed. House of the Higher School of Economics, 2020. - P.10).

In addition to these global natural and macroeconomic problems, there is an acute problem of the technological gap in the development of Russian and world agribusiness precisely in terms of the use of digital technologies. According to Alfiya Kayumova, vice president of the Corporate Development and Investment at Cognitive Technologies company, in the Russian Federation no more than 5,0\% of agribusiness companies really actively use digital technologies, and Russian agribusiness lags behind the EU countries (Germany, France) by 3 times, and from the USA by more than 4 times (Agriculture of high accuracy: how technologies change the Russian agro-industrial complex (23.04.2020). [Electronic Resource]. - URL: https://sber.pro/publication/selskoe-khoziaistvo-vysokoitochnosti-kak-tekhnologii-meniaiut-rossiiskii-apk (date of access 10.03.2021)).

Thus, the relevance of the topic of scientific research is due to the strategic importance of increasing the productivity of the agro-industrial complex Russia to ensure national food security, improving the effectiveness of import substitution policies and bridging the technological gap with global agribusiness leaders, and taking into account the escalation of the problem of sanctions and the chronic nature of the food wars of Russia as with the countries of the near future, as well as far abroad, the issue of forming a new organizational and technological paradigm in the field of the agro-industrial complex is a vital step to ensure the stability of the entire national economy of Russia.

\section{Digital Economy and Industry 4.0. The concept, genesis and role in the formation of agriculture "tomorrow." Review of literature and research (materials and methods)}

The modern stage of the development of the planetary economic system is marked by total digitalization of both the interaction of businesses at the micro level and the implementation of international political and economic relations of countries and their alliances in the format of a positive dualism of interests and goals: on one hand, the digital economy motivates all participants to increase transparency of information and openness to innovation, on other hand, the national interests of states force caution about the 
"informational limitlessness" of space in view of potential challenges and threats from hacker institutions, as well as the transition of competition to virtual space and its scaling to the level of state programs of information warfare. In general, the entire digital economy is based on extreme positive parameters: the motivation for "the availability of personal data and the active development of digital protection institutions," as well as the encouragement of a cross-border digital community and association, goes along with the growth of separatist sentiments and an increase in the autonomy of states [1, c. 59-60].

A review of scientific literature made it possible to establish that for the first time the concept of "Industry 4.0" as a new stage in the development of the world economy was mentioned more than 20 years ago in the work of American informatics N. Negroponte.

In its conceptual presentation, industry 4.0 envisaged the creation of a new design - the digital economy, which has a number of fundamental differences: replacing the physical weight of products with an information volume, the production of electronic goods, the creation of virtual production areas (usually on electronic media), as well as instant global movement through the Internet, but its idea was not widely used due to the lack of readiness of society for such cardinal reforms of socio-economic relations.

In 2011, the world received a second signal that Industry 4.0 is the reality not of the distant future, but of the coming decade, which was proved by the management of the German company Siemens, which acted as the main developer and executor of the Hi-Tech program of Germany's Strategy until 2020.

Thanks to German business, the world again drew attention to radical changes in the organization of the world socio-economic system: if "yesterday" work in a traditional physical format with point interventions of digital technologies was sufficient for the stable functioning of business in particular and national economies in general, today the future has come and traditional physical business models are hopelessly morally obsolete and lose competition right at the start (the very right of business presence in the market without digital reforms in a number of industries (IT, banking) becomes unlikely).

Globally the idea of the digital economy formation was voiced in the report of the American professor K. Schwab at the Davos economic forum only in 2015. The essence of the statement consisted in need of reformatting of an economic system in which the part of a national or global marketplace is assigned to her, and the individual builds with him the communications on the basis of personal interests and preferences that will allow to bring development of all mankind to new qualitative level.

In the world and domestic practice there is no unified definition of the concept "digital economy" today that complicates delimitation of scientific research since the idea of economy of a new format is based on transparency of information and nonlinearity of economic and technological communications within branch ecosystems as a new step of the organizational and administrative device of national economy.

Definition of the concept "digital economy" in domestic and foreign scientific literature is presented in table 1 .

Table 1. Definition of the concept "digital economy" in domestic and foreign scientific literature.

\begin{tabular}{|c|c|}
\hline Author (-s) / source & Content of definition \\
\hline I. Foreign scientific literature & \\
\hline $\begin{array}{l}\text { 1. World Bank report "Digital Government. Prospects for } \\
\text { Russia"( World Bank report "Digital Government. Prospects for } \\
\text { Russia (2016) [Electronic Resource] - URL: } \\
\text { http://pubdocs.worldbank.org/en/473131460040867925/Digital- } \\
\text { Government-Russia-2020-RUS.pdf } \quad \text { (circulation } \\
\text { 02.03.2021, free)) }\end{array}$ & $\begin{array}{l}\text { Digital Economy } \\
\text { qualitatively new } \\
\text { organizational and technical } \\
\text { structure of the economy, } \\
\text { which based on knowledge } \\
\text { and digital technologies for } \\
\text { personalizing products and } \\
\text { services and information }\end{array}$ \\
\hline
\end{tabular}




\begin{tabular}{|c|c|}
\hline & $\begin{array}{l}\text { transparency of public } \\
\text { interactions }\end{array}$ \\
\hline $\begin{array}{l}\text { 2. Delloite analytical review "How the digital economy is } \\
\text { changing business" (How the digital economy is changing } \\
\text { business (20.06.2018) [Electronic Resource] - URL: } \\
\text { https://www2.deloitte.com/ru/ru/pages/about-deloitte/deloitte- } \\
\text { in-press/2018/kak-cifrovaya-ehkonomika-menyaet-biznes.html } \\
\text { (access date 12.03.2021).) }\end{array}$ & $\begin{array}{l}\text { Digitalized economy is a } \\
\text { new cyber-physical system } \\
\text { for implementing business } \\
\text { activity in a virtual format } \\
\text { through the Internet }\end{array}$ \\
\hline $\begin{array}{l}\text { 3. European Commission, 2013: Expert Group on Taxation of } \\
\text { the Digital Economy (Expert Group on Taxation of the Digital } \\
\text { Economy (27.10.2014) [Electronic resource] - URL: } \\
\text { https://ec.europa.eu/taxation_customs/business/company- } \\
\text { tax/tax-good-governance/expert-group-taxation-digital- } \\
\text { economy_en (date of the address of } 11.03 .2021) \text { ) }\end{array}$ & $\begin{array}{l}\text { Digital economy is the } \\
\text { complex multilevel } \\
\text { structure capable to infinite } \\
\text { self-increase by generation } \\
\text { of virtual network knots of } \\
\text { crossing of interests of } \\
\text { separate businesses. }\end{array}$ \\
\hline 4. Fuchs, C [21] & $\begin{array}{l}\text { Digital economy is a new } \\
\text { evolutionary stage in the } \\
\text { organization of economic } \\
\text { relations in society using } \\
\text { the latest digital } \\
\text { technologies and solutions } \\
\text { implemented in a network } \\
\text { format (Internet, IoT) }\end{array}$ \\
\hline 5. M. McLuhan, J. Naisbitt, Y. Masuda & $\begin{array}{l}\text { Digital economy - some } \\
\text { ideal system in which the } \\
\text { prevailing number of agents } \\
\text { and institutes is almost } \\
\text { completely digitized and } \\
\text { chains of creation of added } \\
\text { value are based on the } \\
\text { principles of smart } \\
\text { manufacturing (clever } \\
\text { production) }\end{array}$ \\
\hline $\begin{array}{l}\text { 6.Bazzoun, M. } \\
{[19]}\end{array}$ & $\begin{array}{l}\text { Digital economy is a cyber- } \\
\text { physical system in which } \\
\text { private and public } \\
\text { commercial interests are } \\
\text { realized in a virtual space. }\end{array}$ \\
\hline 3. Collis, A., Brynjolfsson, E [20, p. 142] & $\begin{array}{l}\text { Digital economy is a way of } \\
\text { implementing market } \\
\text { relations taking into } \\
\text { account current } \\
\text { technological trends in the } \\
\text { development of the field of } \\
\text { information and computer } \\
\text { solutions. }\end{array}$ \\
\hline 4. Besada, H. [21] & $\begin{array}{l}\text { Digital economy is a new } \\
\text { business model of the } \\
\text { structure of the national and } \\
\text { global economy, the basis } \\
\text { of which is information } \\
\text { technology, intellectual } \\
\text { capital, intangible assets } \\
\text { and innovation. }\end{array}$ \\
\hline \multicolumn{2}{|l|}{ II. Domestic scientific literature } \\
\hline 1. Strategies for the development of the information $\mathrm{sc}$ & Digital economy is a form \\
\hline
\end{tabular}




\begin{abstract}
the Russian Federation for 2017-2030 (On the Strategy for the Development of the Information Society in the Russian Federation for 2017-2030: Decree of the President of the Russian Federation of 09.05.2017 No. 203 [Electronic Resource] - URL: http://www.kremlin.ru/acts/bank/41919 (access date 19.01.2021, free))
\end{abstract}

2. Averyanova, D.A.

[1]

3enzhabaev, A.T.

[9]

4. Plotnikov, A.V.

[13]

[17]

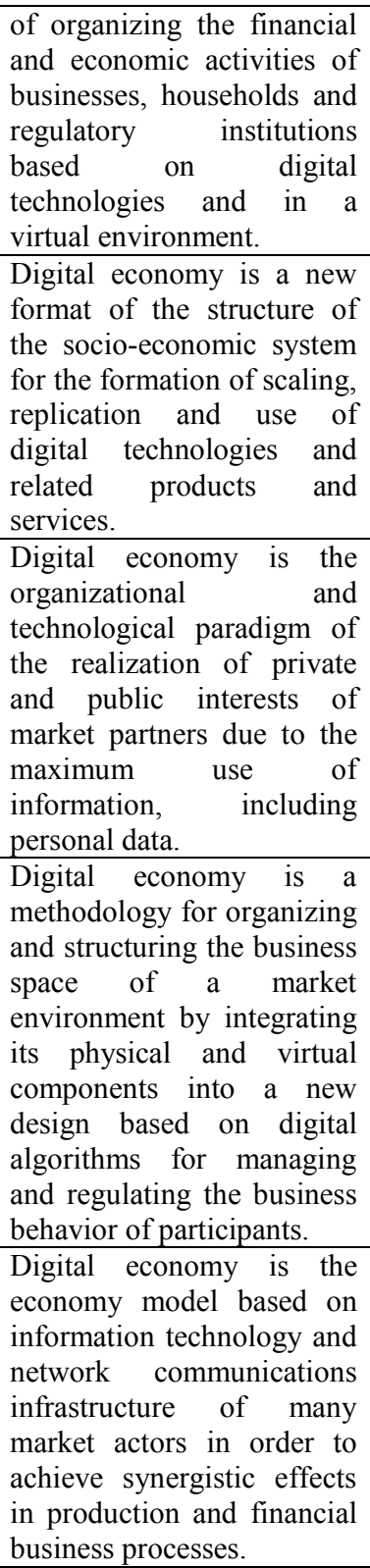

During the consideration of the scientific literature of domestic and foreign scientists, we identified some certain methodological and conceptual features of understanding and interpreting the digital economy:

firstly, in foreign practice (scientific publications M. McLuhan, J. Naisbitt, Y. Masuda), the digital economy is considered as the perfect model with a predominance of fully digitized participants in socio-economic relations, while the value chains themselves work in the format of smart manufacturing [4, p. 58; 5, p. 33];

secondly, in domestic practice, unlike world trends, the digital economy development has a pronounced administrative-personal character, which is confirmed by the content of the following documents: 1) Digital Economy Program (approved by Government Order 1632-r of 28.07.2017); 2) Federal Project "Digital State Management" (approved by the 
minutes of the meeting of the relevant Government Commission No. 9 of 28.05.2019); 3) Decree of the President of the Russian Federation "On the Development of Artificial Intelligence in the Russian Federation" No. 490 of October 10, 2019. In world practice, the initiative and development of a methodology for digitalization of the national economy lies on the side of business - it is he who needs to comfortably realize private commercial interests, and customers need to receive products and services in a new format $[6 ; 7 ; 8]$;

thirdly, in the foreign publications (D. Tapscott, K. Kelly, D. Coyle, D. Schiller, J. W. Cortada) digital economy in the methodological plane is closely related to artificial intelligence and machine communications (robots) as a fundamental component of building the Industry 4.0 system. While in Russian practice scientists (O.V. Dyachenko, E.V. Kupchishina) emphasize the state's orientation on the development of digital infrastructure and state superservices to scale digitalization processes in the market space (for example, the unified and regional portals of state and municipal services have been successfully operating since 2010) [11-15];

fourthly, as follows from the publications of R.H. Weber, E. Schmidt, U. Huws, C. Holroyd, the digital economy is based on the principle of business convergence, including direct competitors, to achieve a synergistic effect of exchanging data about customers and their preferences, that in the long-run time horizon increases the loyalty of the latter to suppliers of benefits, and business can respond better and faster to changing customers' preferences. In the Russian practice of business ethics, digitalization is considered as a tool to ensure long-term protective barriers to entry into the industry or market, thereby motivating successful mega-businesses to monopolize presence markets [16;17].

The scientific literature also focuses on the analysis of global challenges and threats to humanity in terms of their need to digitalize the agro-industrial complex, which are presented in structured form in table 2.

Table 2. Characterization of Global Challenges and Threats Motivating Agribusiness Transition to Digital Business Management Model.

\begin{tabular}{|c|c|}
\hline $\begin{array}{c}\text { Negative challenge /Threat Characteristics (World } \\
\text { Understanding) }\end{array}$ & $\begin{array}{l}\text { Negative challenge / Threat } \\
\text { Characteristics (Russian } \\
\text { understanding) }\end{array}$ \\
\hline $\begin{array}{l}\text { 1. Accelerating the demand growth for agribusiness products } \\
\text { over the resource and production potential of agribusiness, } \\
\text { leading to higher prices and food shortages in the world (food } \\
\text { demand, according to NIC, will grow by } 35 \% \text { by } 2030 \text { due to } \\
\text { the growth of the world population compared to } 2021 \text { (Global } \\
\text { Trends 2030: Alternative Worlds: A Publication of the National } \\
\text { Intelligence Council. } 2012 \text { (December). NIC 2012-001. P. 31- } \\
\text { 38)). }\end{array}$ & $\begin{array}{l}\text { 1. Critically high } \\
\text { dependence on imports of } \\
\text { the national agro-industrial } \\
\text { system for items such as } \\
\text { agricultural technologies } \\
\text { (more than } 80,0 \% \text { ), } \\
\text { functional bio-additives } \\
\text { (more than } 95,0 \% \\
\text { (Innovative development of } \\
\text { the agro-industrial complex } \\
\text { in Russia. Agriculture } 4.0 \\
\text { [Text]: Doc. to XXI Apr. } \\
\text { international scientific. conf. } \\
\text { - Page 59)). }\end{array}$ \\
\hline $\begin{array}{l}\text { 2. Growth in purchasing power of the population (according to } \\
\text { World Data Lab, by } 2030 \text {, the world middle class will reach } 5.3 \\
\text { billion people, while the countries of Southeast Asia will } \\
\text { account for more than } 65.0 \% \text { of the world middle class (Kharas } \\
\text { H. The Unprecedented Expansion of the Global Middle Class: } \\
\text { An Update: Global Economy \& Development Working Paper } \\
\text { 100. } 2017 \text { (February). Brookings Institution, 14. UN World } \\
\text { Population Prospects. P. 14)) }\end{array}$ & $\begin{array}{l}\text { 2. The inefficiency of the } \\
\text { organization and operation } \\
\text { of the land bank due to the } \\
\text { location in the zone of risky } \\
\text { agriculture (according to } \\
2020 \text { data, more than } 97 \\
\text { million hectares, or } 44 \% \text { of } \\
\text { the land is actually preserved } \\
\text { for circulation (Innovative }\end{array}$ \\
\hline
\end{tabular}




\begin{tabular}{|c|c|}
\hline & $\begin{array}{l}\text { development of the agro- } \\
\text { industrial complex in Russia. } \\
\text { Agriculture } 4.0 \text { [Text]: Doc. } \\
\text { to XXI Apr. international } \\
\text { scientific. conf. - Page 60)) }\end{array}$ \\
\hline $\begin{array}{l}\text { 3. Exhaustion of the technical and economic effect of the "green } \\
\text { revolution" (the level of agricultural and biological potential } \\
\text { used for the main crops and varieties of plants is } 85.0-90.0 \% \\
\text { at the end of } 2020 \text { (The world is on the verge of a green } \\
\text { revolution (05.04.2016) [Electronic resource]. - URL: } \\
\text { https://www.hse.ru/news/188171386.html (access date } \\
\begin{array}{l}13.01 .2021) \text { ) }\end{array}\end{array}$ & $\begin{array}{l}\text { 3. Strengthening the } \\
\text { requirements of international } \\
\text { rules and standards for } \\
\text { compliance with sustainable } \\
\text { development, consumption } \\
\text { and environmental } \\
\text { responsibility (bioeconomic, } \\
\text { waste-free production, } \\
\text { environmentally friendly } \\
\text { production) [4] }\end{array}$ \\
\hline $\begin{array}{l}\text { 4. The problem of food losses, biological waste and } \\
\text { unsustainable agriculture (according to FAO, approximately } \\
54 \% \text { of losses occur during the collection and storage of } \\
\text { products, 46\% during the processing, distribution and } \\
\text { consumption stages (Food wastage footprint Impacts on natural } \\
\text { resources (2019) [Electronic resource]. - URL: } \\
\text { https://ec.europa.eu/food/sites/food/files/safety/docs/fw_lib_fao- } \\
\text { 2019_en.pdf (case date 13.01.2021)) }\end{array}$ & $\begin{array}{l}\text { 4. Low penetration of digital } \\
\text { technologies into the agro- } \\
\text { industrial complex: } \\
\text { - According to the Ministry } \\
\text { of Agriculture, the share of } \\
\text { sales of agribusiness } \\
\text { products in the e-commerce } \\
\text { format amounted to less than } \\
10,0 \% \text {; } \\
\text { - According to Skolkovo } \\
\text { Ventures, the share of agro- } \\
\text { industrial enterprises using } \\
\text { digital technologies is less } \\
\text { than } 1,0 \% \text {; } \\
- \text { penetration } \\
\text { agrotechnological innovative } \\
\text { projects into the agro- } \\
\text { industrial complex - less } \\
\text { than 3,0\% (Digital } \\
\text { Agriculture (2019) } \\
\text { [Electronic Resource]. - } \\
\text { URL: } \\
\text { https://ctt.hse.ru/digital } \\
\text { (access date 18.03.2021)) }\end{array}$ \\
\hline
\end{tabular}

\section{Agriculture of the Russian Federation: yesterday, today, tomorrow. Current state and prospects of digital business model's development (results).}

The assessment of the readiness of the Russian agro-industrial complex for digital reforms begins with an analysis of key indicators of its state and role in the national economy for 2014-2019 (table 4).

Table 4. Key indicators of the state of Russian Federation agroindustry for 2014 - 2019

\begin{tabular}{|l|c|c|c|c|c|c|}
\hline \multicolumn{1}{|c|}{ Indicators } & $\mathbf{2 0 1 4}$ & $\mathbf{2 0 1 5}$ & $\mathbf{2 0 1 6}$ & $\mathbf{2 0 1 7}$ & $\mathbf{2 0 1 8}$ & $\mathbf{2 0 1 9}$ \\
\hline $\begin{array}{l}\text { 1. Share of agro-industrial } \\
\text { complex in the country's }\end{array}$ & 3.9 & 4.3 & 4.3 & 3.9 & 3.5 & 3.7 \\
GDP. \% & 7.9 & 2.4 & 2.3 & 1.5 & -2.1 & 3.5 \\
\hline 2. Agroindustry business & &
\end{tabular}




\begin{tabular}{|c|c|c|c|c|c|c|}
\hline dynamics. \% & & & & & & \\
\hline $\begin{array}{lr}\text { 3. State of } & \text { agroindustry } \\
\text { business (PWC } & \text { CIS } \\
\text { methodology) } & \end{array}$ & - & 0.58 & 0.19 & 0.48 & 0.59 & 0.59 \\
\hline \begin{tabular}{lrr}
4. & \multicolumn{2}{c}{ Agro-Industrial } \\
Development & Prospects \\
Index (PWC & CIS \\
methodology) & \\
\end{tabular} & - & 0.33 & 0.39 & 0.19 & 0.22 & 0.35 \\
\hline $\begin{array}{l}\text { 5. Return on investment. } \\
\text { coefficient }\end{array}$ & - & 1.0 & 0.8 & 0.7 & 0.4 & 0.5 \\
\hline $\begin{array}{l}\text { 6. Economic return on } \\
\text { investment and gross value- } \\
\text { added subsidies. coefficient }\end{array}$ & - & 4.3 & 3.9 & 3.5 & 3.4 & 3.4 \\
\hline 7. Rentability of products. $\%$ & 20.7 & 25.8 & 21.9 & 16.0 & 17.0 & 15.4 \\
\hline
\end{tabular}

Note: Sources: Comparative analysis of the operational efficiency of the agricultural sector of Russia [Electronic resource]. - URL: https://www.pwc.ru/ru/agriculture/operational-efficiency.pdf (access date 10.01.2021);

Agro-industrial complex. Statistics of the Eurasian Economic Union [Electronic Resource]. - URL: http://www.eurasiancommission.org/ru/act/integr_i_makroec/dep_stat/econstat/Documents/Agricultur e_Statistics_Yearbook_2020.pdf (access date 10.01.2021);

(Ägricultural Market Overview - 2019 [Electronic Resource]. - URL:

https://ru.investinrussia.com/data/file/obzor-rynka-selskogo-hozyajstva-2019.pdf (access date 10.01.2021).

As it can be seen from the previous table, Russian agroindustry is fairly stable in terms of the contribution to the country's GDP: on average, this indicator amounted to 3,9\%, while the dynamics of business activity of enterprises in the agro-industrial sector decreased markedly, starting in 2015, and in 2018 there was a negative trend in reducing business activity by 2,1 percentage points. However, taking into account the active subsidization and implementation of national and federal financial assistance programs for agro-industrial enterprises (the volume of state support increased from 179 billion rubles in 2014 to 304 billion rubles in 2019), the index "State of agro-industrial complex," calculated according to the methodology of the consulting agency PWC CIS, amounted to an average of 0,49 , which allows us to say that agribusiness management estimates its current position as stable, but the indicator "Prospects for the development of agro-industrial complex" amounted to an average of 0,29 , which is an unsatisfactory criterion for assessing the prospects for business development in the agricultural sector.

At the next stage, we will consider the indicators of innovative activity of agribusiness enterprises for 2014-2019 and give an assessment of their interest in implementing digital reforms (Table 5).

Table 5. Indicators of the agro-industrial businesses innovative activity for 2016-2020 years.

\begin{tabular}{|l|c|c|c|c|c|}
\hline \multicolumn{1}{|c|}{ Indicators } & $\mathbf{2 0 1 6}$ & $\mathbf{2 0 1 7}$ & $\mathbf{2 0 1 8}$ & $\mathbf{2 0 1 9}$ & $\begin{array}{c}\mathbf{2 0 2 0} \text { (pre- } \\
\text { value) }\end{array}$ \\
\hline $\begin{array}{l}\text { 1. Share of agro-industrial } \\
\text { complex organizations } \\
\text { implementing technological } \\
\text { innovations. \% (average) } \\
\text { Including: }\end{array}$ & 2.88 & 3.44 & 9.8 & 11.64 & 13.06 \\
\hline 1.1 Crop production & 5.9 & 7.5 & 7.4 & 8.2 & 9.1 \\
\hline $\begin{array}{l}1.2 \quad \text { Seedlings and } \\
\text { Greenhouse Business }\end{array}$ & 2 & 2.1 & 14.3 & 16.9 & 18.3 \\
\hline 1.3 Animal husbandry & 2.8 & 3.9 & 4.7 & 5.2 & 6.5 \\
\hline 1.4 Mixed agriculture & 1.1 & 1.3 & 16.3 & 20.4 & 22.7
\end{tabular}




\begin{tabular}{|c|c|c|c|c|c|}
\hline $\begin{array}{l}1.5 \text { Agroindustry Auxiliary } \\
\text { Business }\end{array}$ & 2.6 & 2.4 & 6.3 & 7.5 & 8.7 \\
\hline $\begin{array}{l}\text { 2. The volume of } \\
\text { investments in technological } \\
\text { innovations in the agro- } \\
\text { industrial complex. total } \\
\text { million rubles. } \\
\text { Including: }\end{array}$ & 14963.3 & 15806.0 & 21960.5 & 26854.3 & 35074.8 \\
\hline $\begin{array}{lll}2.1 & \text { Research and } \\
\text { Development } & \end{array}$ & 1990.1 & 4409.1 & 2707.3 & 2962.5 & 4113.5 \\
\hline 2.2 Acquisition of Machinery & 9336.9 & 7705.3 & 14553.8 & 16741 & 19633.6 \\
\hline 2.3 Engineering & 1646 & 2137.8 & 1886.5 & 2338.4 & 2707.6 \\
\hline $\begin{array}{l}2.4 \text { Acquisition of new } \\
\text { technologies and software } \\
\text { tools }\end{array}$ & 3261 & 25.9 & 137.4 & 3152.4 & 3289.8 \\
\hline 2.5 Other investments & 912.7 & 1288 & 2562.4 & 1660.0 & 5330.3 \\
\hline $\begin{array}{l}\text { 3. Total investments in agro- } \\
\text { industrial complex } \\
\text { digitalization. RUB mln. (pg. } \\
2.1+\text { pg. } 2.3+\text { pg. } 2.4 \text { ) }\end{array}$ & 6897.1 & 6572.8 & 4731.2 & 8453.3 & 10110.9 \\
\hline $\begin{array}{l}\text { 4. The volume of innovative } \\
\text { agro-industrial products. } \\
\text { million rubles. }\end{array}$ & 22222.9 & 28446.0 & 33829.1 & 30207.6 & 29887.8 \\
\hline $\begin{array}{l}\text { 5. Investment return index } \\
\text { for agro-industrial complex } \\
\text { digitalization (page } 4 / \text { page } 3 \text { ) }\end{array}$ & 3.2 & 4.3 & 7.2 & 3.6 & 3.0 \\
\hline $\begin{array}{lr}\text { 6. Innovative } & \text { activity of } \\
\text { agro-industrial } & \text { complex } \\
\text { organizations } & \\
\end{array}$ & & & & & \\
\hline $\begin{array}{l}6.1 \text { Worldwide (average } \\
\text { estimate) }\end{array}$ & 10.6 & 12.4 & 14.2 & 15.6 & 17.1 \\
\hline 6.2 Russian Federation & 4.0 & 3.7 & 5.4 & 5.8 & 7.2 \\
\hline
\end{tabular}

Note :

Indicators of innovation: 2018: statistical collection/N.V. Gorodnikova, L.M. Gokhberg, K. A. Ditkovsky and others; Natz. researched. un I60 "Higher School of Economics." - M.: HSE, 2018. Page 63; 70; 92; 98; 103.

Indicators of innovation: 2019: statistical collection/L. M. Gokhberg, K. A. Ditkovsky, I. A.

Kuznetsova and others; Natz. researched. un-t "Higher School of Economics." - M.: HSE, 2019. -

Page $17 ; 28 ; 33 ; 40 ; 49 ; 61 ; 67 ; 78$.

Indicators of innovation: 2020: statistical collection/L. M. Gokhberg, K. A. Ditkovsky, E. I. Evnevich and others; Natz. researched. un I60 "Higher School of Economics." - M.: HSE, 2020. - Page 19; 39; $42 ; 47 ; 58 ; 63 ; 70 ; 102$.

As follows from the previous table, among the organizations of the agro-industrial complex, the most active in terms of innovation and the development of digital technologies were seedlings and greenhouse farms - on average, they accounted for $10,7 \%$ of all technological innovations in the agro-industrial complex, in second place - businesses leading a mixed economy $-12,4 \%$. When analyzing investments in the development of digital innovations, it was found that on average 33,9\% of all investment expenses, with extremes occurring in 2016 and 2017. - 46,1\% and 41,6\%, respectively. The return on investment in the digitalization of agro-industrial complex averaged 4,2. The innovation activity index in the world averaged $14.0 \%$, in the Russian Federation $-5,2 \%$. The implementation of such a large-scale project as the digitalization of the agro-industrial complex is impossible without determining the main technological milestones of 
development, according to which it will be possible to evaluate the effectiveness of the implementation of digital reforms by agribusiness within the industry (Table 6).

Table 6. Main technological milestones of implementation of digital reforms in agro-industrial complex Russia.

\begin{tabular}{|c|c|}
\hline $\begin{array}{l}\text { Technological milestone } \\
\text { (chronological boundaries) }\end{array}$ & Description of the content of the technological milestone \\
\hline $\begin{array}{l}\text { 1. Milestone of point } \\
\text { digitalization }(2010-2020)\end{array}$ & $\begin{array}{l}\text { Characteristics of the stage. Use individual digital advances } \\
\text { to automate routine business processes or replace manual } \\
\text { labor with mechanically robotic (mixed work format). } \\
\text { The main points of digitalization application: monitoring of } \\
\text { the state of the land bank, analysis of the state of crops, state } \\
\text { control and protection of the working and breeding cattle, } \\
\text { remote management of life support processes and farm } \\
\text { infrastructure. } \\
\text { Examples of digital products: UAVs for spraying fertilizers } \\
\text { and monitoring the state of the land, sensors of the biological } \\
\text { state of cattle, pigs, AI-systems for managing individual } \\
\text { business processes (watering, temperature, lighting) in the } \\
\text { greenhouse and farm (food, water, vitamins (Catalogue of } \\
\text { autonomous agricultural robots for work in a field, in a } \\
\text { garden or greenhouse (2020) [Electronic resource]. - URL: } \\
\text { http://robotrends.ru/robopedia/katalog-avtonomnyh-robotov- } \\
\text { dlya-raboty-v-selskom-hozyaystve (access date 11.03.2021)). }\end{array}$ \\
\hline $\begin{array}{l}\text { 2. Milestone of digitalization of } \\
\text { individual agribusinesses (2020- } \\
\text { 2025) (Ivanov, A. Moiseev, V. } \\
\text { Agriculture in a smart } \\
\text { way//CONTROL } \\
\text { ENGINEERING RUSSIA } \\
\text { (2017) [Electronic resource]. - } \\
\text { URL: https://controleng.ru/wp- } \\
\text { content/uploads/iot_35.pdf (date } \\
\text { access 11.03.2021)) }\end{array}$ & $\begin{array}{l}\text { Characteristics of the stage. Aggregation of separately } \\
\text { digitized business processes into a holistic business model at } \\
\text { the level of individual farms or holding structures using end- } \\
\text { to-end digitalization technologies with subsequent transfer of } \\
\text { rights to the operational management of the AI mechanism. } \\
\text { The main points of digitalization application: production } \\
\text { chains "from field to farm" and "from farm to table" by } \\
\text { implementing monitoring and process management in real } \\
\text { time and in the format of start-to-end. } \\
\text { Examples of digital products: robotic plants for processing } \\
\text { agricultural products, automated complexes of machine } \\
\text { sowing and harvesting, autonomous feeding and milking } \\
\text { systems of cattle, autonomous platforms of procurement and } \\
\text { service functionality for automation of supply and service } \\
\text { processes. }\end{array}$ \\
\hline $\begin{array}{l}\text { 3. The milestone of robotic } \\
\text { farms }(2025-2035)\end{array}$ & $\begin{array}{l}\text { Characteristics of the stage. Transfer of up to } 80.0 \% \text { of all } \\
\text { work in agriculture to operational robotic mode (with this } \\
\text { mode, personnel only coordinate the work of robot teams). } \\
\text { AI mechanisms and IoT systems coordinate the } \\
\text { communication of robots and control them in network mode. } \\
\text { Main points of digitalization application: autonomous } \\
\text { agricultural robots, nanorobots for pest control and } \\
\text { weeds, drones with artificial intelligence to assess the state of } \\
\text { crops and soil. } \\
\text { Examples of digital products: robotic agricultural machinery } \\
\text { control systems, precision farming, nanorobots-fertilizer } \\
\text { injectors, robot bees for pollination of plants }\end{array}$ \\
\hline $\begin{array}{l}\text { 4. Field farm milestone managed } \\
\text { by bots command }(2035-2050) \\
\text { (Robots for fields: overview of } \\
\text { intelligent } \quad \text { agricultural } \\
\text { machinery } \quad(03.04 .2019) \\
\end{array}$ & $\begin{array}{l}\text { Characteristics of the stage. Replacing bulky agricultural } \\
\text { machines with miniature robot bots performing simple } \\
\text { operations (ploughing, sowing, fertilizer, harvesting) on a } \\
\text { limited plot of land, and the entire farm will be one field } \\
\text { controlled by a network of bots with AI functionality. }\end{array}$ \\
\hline
\end{tabular}


[Electronic resource]. - URL: https://agbztech.ru/article/robotsfor-fields-review-of-intelligentagricultural-equipment/ (date access 11.03.2021))
The main points of digitalization application: artificial intelligence, bio- and nanorobots with the possibility of placing them in water or spraying in the air, genetic modified plants with new properties (glow in the dark for round-theclock pollination).

Examples of digital products: nanorobots and biological robots capable of interacting with each other in a certain environment (water).

The result of the digitalization of the agro-industrial complex should be a mechanism for managing the relationships of stakeholders based on a group of digital platforms:

1. Platform No. 1 "Digital Agriculture" - providing virtual management of the processes of production of primary agricultural products, analysis and assessment of the qualitative and quantitative parameters of seed material, crops, livestock condition. This platform is integrated with the largest suppliers of biological assets, seeds, fertilizers, agricultural equipment.

2. Platform No. 2 "Agricultural Solutions" is an information and analytical marketplace that uses AI tools to generate forecasts of the state of the agricultural market, submit financing requests to the bank and government subsidies, manage technical groups through the Internet of Things (IoT), and organize export and import deliveries.

3. Platform No. 3 "Center of Competencies" is a cross-functional marketplace that combines both agribusiness and educational institutions that train personnel for the agroindustrial complex. Within the framework of this platform, it is planned to organize special training programs for specialists with digital competencies, as well as the development of an independent branch in the IT field, focused on the needs of agriculture.

4. Platform No. 4 "Experimental Digital Farms" is a pilot platform for testing innovative technologies and developments in the field of business process management in the agroindustrial complex with the involvement of financing venture funds, as well as the infrastructure of technology parks (Figure 1).

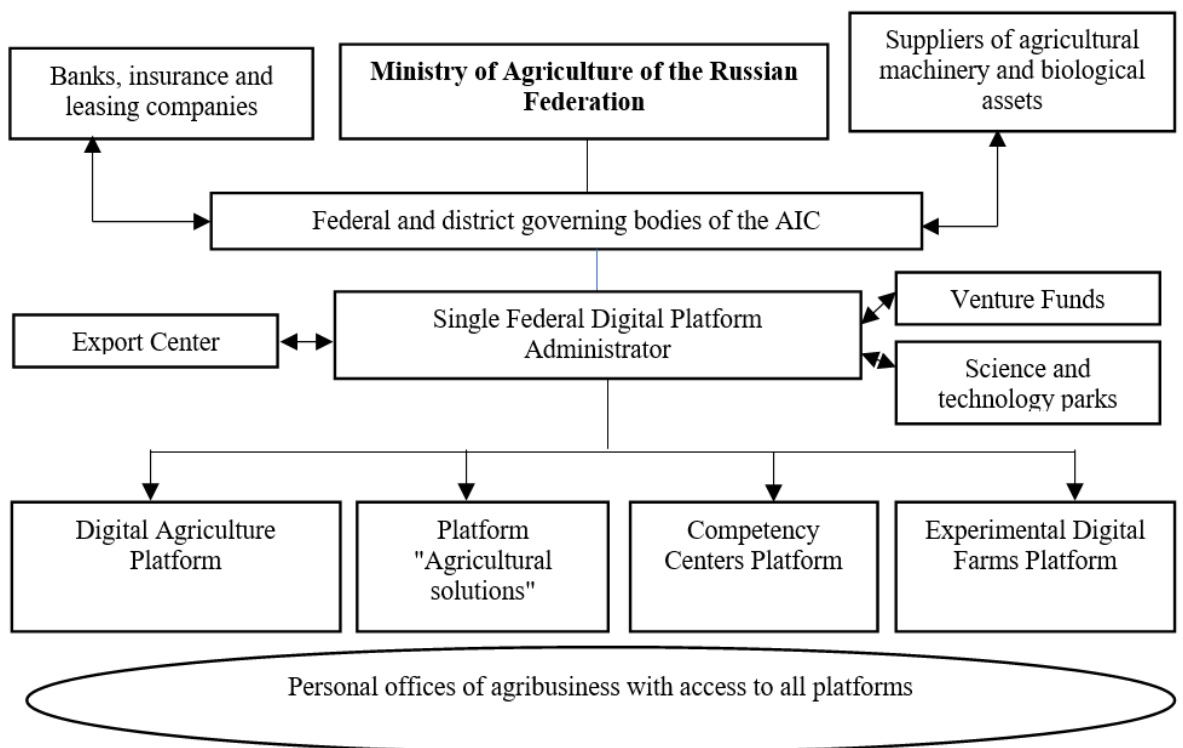

Fig. 1. Agro-industrial complex stakeholders relationship management mechanism based on digital platform group. 
The analysis of the state of the agro-industrial complex in the Russian Federation shows the objective need for the speedy introduction of digital technologies into the business processes of agricultural production. At the same time, despite the state measures taken to support agribusiness to carry out digital reforms of the technological organization and management of agricultural processes, a number of problematic points of implementation of agribusiness digitalization projects remain. To better understand and assess the digital gap in the development of the agro-industrial complex of Russia and the world, we analyzed the results of the expert survey "Digitalization of Private Business in Central and Eastern Europe" (CEE) conducted by the PWC CIS (Figure 2).

As it follows from the figure in Russian Federation the main problematic points are the shortage of financing for digitalization projects of business processes of agro-industrial enterprises with the general dependence of the agro-industrial sector on budget subsidies and the presence of a single departmental project "Digital Agriculture" (Innovative development of the agro-industrial complex in Russia. Agriculture 4.0 [Text]: Doc. to XXI Apr. international scientific. conf. - Page 29-30), which also manages the distribution of state financing. The second most important place is occupied by a shortage of personnel with digital competencies for working in the agro-industrial complex (according to end of 2018, only 12 universities offered special disciplines in the curricula for the development of digital competencies of agro-industrial complex employees (Truflyak E.V. Using elements of precision agriculture in Russia/E.V. Truflyak. - Krasnodar: KubGAU, 2018. - Page 18), in third place among problem points is the internal resistance of staff to digital reforms.

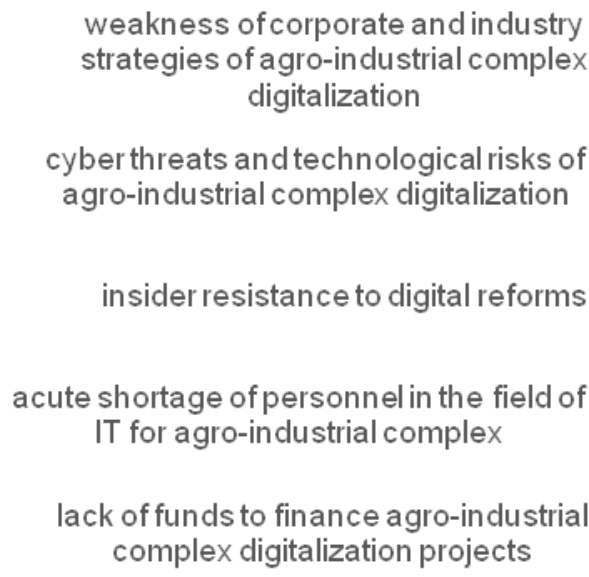

weakness of corporate and inclustry strategies of agro-industrial complex digitalization

cyber threats and technological risks of agro-industrial complex digitalization

insider resistance to digital reforms complex digitalization projects

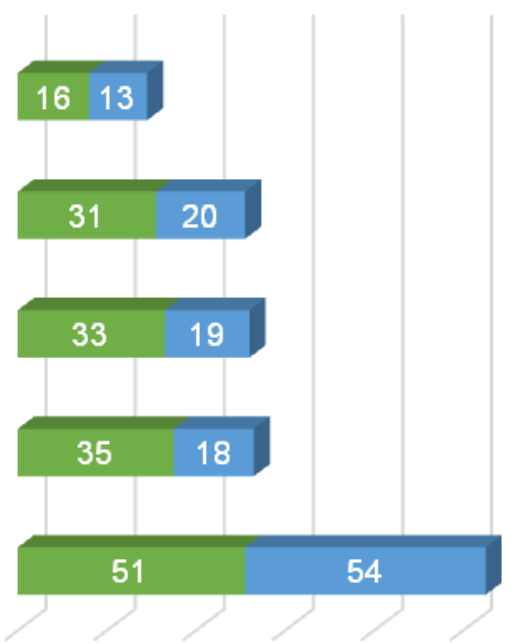

$\begin{array}{llllll}0 & 20 & 40 & 60 & 80 & 100\end{array}$

\section{- Russia Central and Eastern Europe countries}

Fig. 2. Comparative analysis of problem points of agro-industrial complex digitalization in the Russian Federation and Central and Eastern Europe countries (Digitalization of private business in Central and Eastern European countries (2019) [Electronic resource]. - URL:

https://www.pwc.ru/ru/assets/emea-private-business-survey.pdf (case date 12.03.2021)).

In conclusion, we will conduct a comparative analysis of the priority areas of development of digital technologies in the agro-industrial complex for the next 3-5 years in the Russian Federation and the CEE countries (Figure 3). 


\section{Transferring $\mathrm{AlC}$ business data to cloud terminals, Big AgroData development \\ creation of loT networks for agricultural machinery management \\ robotization of business processes of sowing. harvesting \\ introduction of complex products based on artificial intelligence for farm management \\ Use of UAVs and low-orbit satellites to monitor the condition of farmland \\ blockchain tools and smart contracts for financial support of agribusiness}

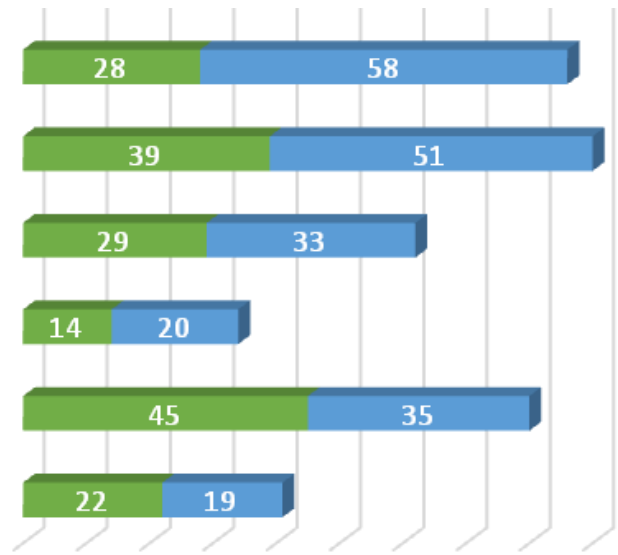

$\begin{array}{llllllllll}0 & 10 & 20 & 30 & 40 & 50 & 60 & 70 & 80 & 90\end{array}$

- Russia Central and Eastern Europe countries

Fig. 3. Priority directions of development of digital technologies in agro-industrial complex for the next 3-5 years in the Russian Federation and CEE countries (Digitalization of private business in Central and Eastern European countries (2019) [Electronic resource]. - URL:

https://www.pwc.ru/ru/assets/emea-private-business-survey.pdf (access date 12.03.2021)).

As follows from the data of the drawing in the Russian Federation, the most interesting in terms of the development of digital technologies are the use of UAVs and low-orbit satellites for monitoring the state of farmland $-45,0 \%$, in second place is the creation of IoT networks for managing agricultural machinery and its autonomous work $-39,0 \%$, the third place was taken by tools for robotizing sow and harvest - 29,0\%. I.e. Russian agroindustrial enterprises, unlike foreign ones, consider digital technologies exclusively utilitarian and focus on those solutions that require minimal infrastructure transformations, and also pay off faster through direct participation in production processes.

\section{Business models of agro-industrial enterprises of tomorrow (discussion)}

The Russian agrobusinesses have several options of realization of digitalization of own business models:

1. A business model of Next Giant - formation of own agroecosystem of a full cycle of production and selling of agricultural products. Within uniform space the participants of the sphere of agrarian and industrial complex segmented on activities or the rendered services will be combined with the help of smart contracts. As base for their collaboration the virtual platform where each of participants will have the private office will act and also the library of contractors, the center of financing of agrarian and industrial complex (the key player JSC Rosselkhozbank), the block of services and discussion of the strategy of development for an agroecosystem will be separately taken out [7].

Example of almost functioning agroecosystem is vertically integrated holdings in the sphere of agrarian and industrial complex of PJSC Cherkizovo, PJSC Rusagro having debugged model of business processes of own supply with biological assets, production capacities for maintaining a portfolio of the directions of agrobusinesses (in their PJSC Cherkizovo 4, in PJSC Rusagro - 6) and also own logistic and retail chain stores.

2. Limited partnership - involvement by the large player in the market of agrarian and industrial complex to the sphere of the business conduct of the highly specialized 
companies or services for the solution of thematic tasks or transfer on outsourcing of routine processes. Also perhaps and the return movement when large players form the pool on the basis of limited partnership (in difference from holding structures they keep the autonomy regarding business management) [8]. An example of such model it is possible to call the Russian grain unions operating in the Russian Federation, the Dairy union of Russia, National meat association and other which act as branch lobbies platforms now, and in the long term I can create own venture funds for development of innovative solutions according to specifics of the direction (Industry unions and associations of agro-industrial complex [Electronic resource]. - URL: https://www.agroxxi.ru/poleznye-kontakty-apk/ot raslevye-soyuzy-i-associacii-apk.html (case date 17.01.2021)).

3. Innovators - new forms of the organization of business processes in agrarian and industrial complexes which are revolutionary for the Russian market, for example: urbanistic vertical farms in shopping centers, or in territories of the liquidated industrial enterprises with shop structure (an example - iFARM, Novosibirsk); crowd-pharming with the organization of access to process of production of food by everyone (actually, it is the new version of the commune or community, only with digital technologies), FoodNet is the organization of small production forms for cultivation of products taking into account features of needs of the concrete area of residence of citizens or seasonal (incidental) splashes in diseases or the shortage of concrete vitamins (for example, deficiency of vitamin D at residents of Far North; formation of thematic diets for people with an excess weight, etc.) $[9 ; 10]$. service.

\section{Conclusion}

According to the results of the scientific study, the problems of the development of digital business models of agro-industrial enterprises in domestic and foreign practice were studied. In the world, interest in digitalization of business models of agro-industrial enterprises is associated with global problems of food shortages and climate problems; increasing urbanization and the aggregate population of the world; exhaustion of growth resources through the II Green Revolution; increasing demand for clean food and interest in personalizing the food and service market.

For the Russian Federation, which is critically close to the transition to the level of development of advanced business practices, AgFunder distinguish three main groups of innovative technologies: industrial technologies "from farm to counter"; consumer technologies "from the counter to the plate"; Transitional (infrastructure) technologies that provide the most efficient implementation of digital practices in the organization and management of business processes in the field of agribusiness. According to the results of a scientific study, agribusiness in the Russian Federation is recommended to pay attention to the following areas of smart development of the agro-industrial sector, based on the use of the artificial intelligence mechanism: accurate agriculture; smart farms; smart greenhouses.

\section{References}

1. A.A. Aitpaeva, Bulletin of Astrakhan State Technical University. Series: Eco-nomics 3, 56 - 63 (2019) DOI: 10.24143/2073-5537-2019-3-56-63

2. D.C. Booklagin, International Research Journal 2(1), 136 - 154 (2021) DOI:10.23670/IRJ.2021.103.2.026

3. É.L. Bolfe, L.A. de C. Jorge, I.D. Sanches, et al, Agriculture (Switzerland) 10(12), 116 (2020) DOI: 10.3390/agriculture10120653 
4. N. Chergui, M.T. Kechadi, M. McDonnell, International Multi-Conference on: Organization of Knowledge and Advanced Technologies, OCTA 2020 (2020) DOI: 10.1109/OCTA49274.2020.9151851

5. S. Fountas, B. Espejo-Garcia, A. Kasimati, et al, IT Professional 22(1), 24-28 (2020) DOI: 10.1109/MITP.2019.2963412

6. C. Florey, J. Hellin, J. Balié, Enterprise Development and Microfinance 31(2), 126140 (2020) DOI: 10.3362/1755-1986.20-00007

7. J. Ingram, D. Maye, Frontiers in Sustainable Food Systems 4 (2020) DOI: 10.3389 /fsufs. 2020.00066

8. A.T. Kenzhabaev, Economics and business: theory and practice 1-1, 143 - 147 (2021) DOI: $10.24411 / 2411-0450-2021-1033$

9. A. Lajoie-O’Malley, K. Bronson, S. van der Burg, et al, Ecosystem Services 45 (2020) DOI: 10.1016/j.ecoser.2020.101183

10. A.M. Pukach, Bulletin of agrarian science 4, 153-158 (2019) DOI: 10.15217/48484

11. T. Ravis, B. Notkin, Berkeley Planning Journal. University of California, Berkeley (2020) DOI: 10.5070/BP331044067

12. M. Shepherd, J.A. Turner, B. Small, et al, Journal of the Science of Food and Agriculture 100(14), 5083-5092 (2020) DOI: 10.1002/jsfa.9346

13. O.V. Shumakova, O.N. Kryukova, Bulletin of Agrarian Science 1, 143 - 152 (2021)

14. A.A. Tuskov, Models, systems, networks in economics, technology, nature and society 1(25), 55 - 64 (2018)

15. V.M. Volodin, Economic sciences 2, 13 -23 (2019) DOI 10.21685/2309-2874-2019-22

16. B.A. Voronin, Agricultural Bulletin of the Urals 2, $39-46$ (2019) DOI 10.32417/article_5cb0b27b458600.04669366

17. I. Aleksandrov, A. Burmistrov, O. Rasskazova, M .Fedorova, IOP Conference Series: Materials Science and Engineering 497 (2019) DOI: 10.1088/1757$899 X / 497 / 1 / 012003$

18. S.D. Vlasov, Vestnik of Saratov St. Soc.-Ec. Univ., 106-109 (2013)

19. M. Yu. Sheresheva, M. S. Oborin, O.V. Shimuk, Perm University Herald. Economy 12(4), 634-46 (2017) DOI: 10.17072/1994-9960-2017-4-632-648

20. O. Lisova, V. Erokhin, A. Ivolga, App. St. Agrobis. \& Com. 10(1), 45-52 (2016) DOI: 10.19041/APSTRACT/2016/1/6

21. I. Aleksandrov, M. Fedorova, E3S Web of Conferences 110 (2019) DOI $10.1051 / \mathrm{e} 3$ sconf $/ 201911002019$

22. T. Tikhonova, O. Shik, Alternative Employment in Rural Area in Russia (Institute for Economic Policy, Moscow, 2008) https://iep.ru/files/text/working_papers/114.pdf

23. A. S. Bahaman, H. A. M. Shaffril, J. L. D'Silva, As. Soc. Sci. 6(4), 136-44 (2010)

24. F. Islam, M.M.H. Kazal, M.H. Rahman, Prog. Agr. 2(27), 207-15 (2016)

25. V. E. Cherkasov, E.V. Vakhovsky, Bul. of Vol. Reg. Inst. of Adm., 205-212 (2012)

26. N. V. Tonkikh, T. A. Kamarova, Her. of Omsk Un.. Ser. Ec. 58(2), 185-96 (2017)

27. B.A., Musayev, Naukoved. 9(2), 1-7 (2017)

28. D. Strebkov, A. Shevchuk, M. Ros. 24(1), 72-100 (2015)

29. First Russian census of freelancers (2008) https://docplayer.ru/40420058-Itogi-pervoyvserossiyskoy-perepisi-frilanserov-v-diagrammah-i-grafikah.html 
30. Second Russian census of freelancers (2011) https://docplayer.ru/38136421-Itogiperepisi-fri-lanserov-2011-g-v-diagrammah-i-grafikah.html

31. V.V. Radaev, Rynki udalennoj raboty socialnye seti i instituty (HES, Moscow, 2012)

32. A.H.F. Li, Ch. Persp. 3, 57-62 (2017) DOI: https://doi.org/10.4000/chinaperspectives.7423

33. N. Sukasame, T.C. Sebora, A. Mohedano-Suanes, Ser. Ind. J. 28(7), 989-1001 (2008) DOI: $10.1080 / 02642060701861357$

34. V. Plotnikov, O. Pirogova, Y. Vertakova, IOP Conf. Ser.: E. \& Env. Sci. 272 (2019) DOI: $10.1088 / 1755-1315 / 272 / 3 / 032225$

35. I. Aleksandrov, M. Fedorova, MATEC Web of Conferences 170 (2018) DOI: 10.1051/matecconf/201817001011

36. L.V. Bondarenko, Zanatost na sele i resursnoye obespechenie malogo biznesa selskimi bezrabotnimi, http://www.vniiesh.ru/documents/document_9617_/

37. Russian Public Opinion. Entrepreneurship in Russia: Confidence, Barriers And Success Factors (VCIOM, 2017) https://wciom.ru/index.php?id=236\&uid=3605

38. A. B. Neustroyeva, O. V. Popova, Arc. \& Subarc. Nat. Res. 3 (2014)

39. S. A. Sukneva, A. S. Barashkova, A.B. Neustroyeva, Reg. Ec.: Theo. \& Pr. 15(7), 1251-60 (2017) DOI: 10.24891/re .15.7.1251

40. E.S. Sorokina, O.A. Glazunova, Res. Bul. of Belg. St. Un.. Ec. Inf. 204(7), 55-86 (2015)

41. Data Insight (2019) http://www.datainsight.ru/ecommerce_201

42. M. Zeng, Ad. in Ec., Bus. \& Man. Res. 68, 540-45 (2018)

43. C. X. Zhai, C. Gao, Y. Xiao, Z. Zhao, Z. W. Sun, IOP Conf. Series: Materials Science and Engineering 062143, 392 (2018) DOI: 10.1088/1757-899X/392/6/062143

44. J. Oláh, N. Kitukutha, H. Haddad, M. Pakurár, D. Máté, J. Popp, Sust. 89, 11 (2019) DOI: $10.3390 /$ su1 1010089

45. T. Makkonen, T.J. Hokkanen, T. Morozova, M.E. Suharev, Euras. Geog. \& Ec., 685707 (2019) DOI: 10.1080/15387216.2019.1593209 